\title{
Studies on Growth, Competition Functions and Productivity of Baby Corn-cowpea Intercropping System under Various Crop Geometryand Nutrient Management
}

\author{
M. Karmakar ${ }^{1 *}$, A. K. Barik ${ }^{1}$ and S. K. Ghorai \\ ${ }^{1}$ Dept. of Agronomy, Institute of Agriculture, Visva-Bharati, Sriniketan, Birbhum, West Bengal (731 235), India \\ ${ }^{2}$ E. I. Dupont Private Limited, Barasat, North 24 Pargana, West Bengal, India
}

\section{Corresponding Author}

M. Karmakar

e-mail: karmakar.mrinmoy21@gmail.com

\author{
Article History \\ Article ID: AR1827a \\ Received in $17^{\text {th }}$ July, 2017 \\ Received in revised form $17^{\text {th }}$ September, 2017 \\ Accepted in final form $29^{\text {th }}$ October, 2017
}

\begin{abstract}
A field experiment was conducted during kharif season of 2012 and 2013 at agricultural research farm, Palli Siksha Bhavana (Institute of Agriculture), Visva-Bharati, Sriniketan, West Bengal to study the effect of crop geometry and nutrient management in baby corn and cowpea (fodder) intercropping system on growth, productivity and competition functions of intercropping systems. The experiment was laid out in randomized block design having twelve treatments with each treatment replicated thrice. Higher number of corns ha-1 ${ }^{-1}$ baby corn yield and green fodder yield of baby corn and cowpea were found in sole crop of baby corn and cowpea. This was significantly higher than various intercropping systems. Total green fodder yield from different intercropping systems was higher than sole cowpea but lower than sole baby corn. The treatment having 3:1 row ratio of baby corn and cowpea 100\% NPK of base crop $+75 \%$ PK of intercrop exhibited significantly higher total fodder yield over sole crop of cowpea and lower than sole crop of baby corn. Baby corn+cowpea (fodder) at 2:2 row ratio with $100 \%$ NPK of base crop $+75 \%$ PK of intercrop exhibited the highest LER, monetary advantage (MA) and Area-time equivalent ratio (ATER) followed by baby corn+cowpea (2:1) with $100 \%$ NPK of base crop $+75 \%$ PK or $50 \%$ PK of intercrop. However, the highest Relative Value Total (RVT) and Aggressivity (A) was recorded in 3:1 row ratio of baby corn and cowpea with $100 \%$ NPK of base crop $+75 \%$ PK of intercrop and with $100 \%$ NPK of base crop $+25 \%$ PK of intercrop respectively. The Relative Crowding Co-efficient (RCC) was observed in 2:1 row ratio of ratio of baby corn and cowpea with $100 \%$ NPK of base crop $+75 \%$ PK of intercrop.
\end{abstract}

Keywords: Baby corn, cowpea, intercropping, nutrient management, competition functions

\section{Introduction}

Cereal-legume intercropping grown bothforthe green fodder and seeds are valued for the important role they play in sustainableagriculture (Andersen et al., 2007). Moreover, in farming organically managed and sustainable agricultural systems, growing crops in mixtures has become an important element (Lithourgidis et al., 2011). The agro industrial wastes such as pineapple waste, sugarcane molasses, the peel, husk or silk of sweet corn and baby corn are also used as dairy feed (Sruamsiri, 2007). Baby corn, a specialized vegetable, is one of the most promoted crops in Thailand. The area planted in crop years 1983-85 was about 16,800 acres which produced about 44,000 t of fresh ears annually, of which only $20 \%$ was used as human food. The rest, mainly husk and silk, could have been used as green herbage for ruminants and pigs. It was suggested that baby corn wastages be used as supplementary roughage (Cheva-Isarakul et al., 1988). In the last one and a half decade, baby corn has emerged worldwide as one of the high value crops due to its high nutritive value and exotic taste. This can serve as fresh fodder in the region as well for which there is a high dearth. To sustain the heavy cattle population in the region baby corn can provide a valuable supplementary source of green fodder particularly for milch animals. Recently the dairy farms surrounding the urban areas have increased in number due to the growing need of milk and milk products for the urban people. So to sustain the dairy industries it is essential to increase fodder production. Supply of forages is inadequate in the country not only in terms of quantity but quality as well. Since the scope of area expansion under cultivated fodder ( $5 \%$ of cultivable area) is limited, the productivity of fodder crops is to be raised through best utilization of the resources of the prevailing production systems. Intercropping of botanically diverse crop species like cereals (baby corn as food) and legumes (fodder) appears to be one of the feasible approaches for increasing the food and herbage yield, utilization of land more efficiently, improving the forage quality and providing stability to production. Baby corn and cowpea, the potential food and forage crops, are adaptable to wide range of environment and can provide nutritious food and fodder under rainfed conditions when 
grown in association. Hence, a rational approach is required on appropriate crop geometry and nutrient management of baby corn and cowpea in an intercropping system. Since information on intercropping of food and forage (baby corn with cowpea) is not adequate under rainfed conditions in semi-arid regions, this field experiment was conducted with the objectives to study growth productivity and competition functions of baby corn and cowpea (fodder) in sole as well as intercropping system under different crop geometry and nutrient management.

\section{Materials and Methods}

A field experiment was carried out at Agricultural Farm of Palli Siksha Bhavana (Institute of Agriculture), Visva-Bharati, Sriniketan situated at $23^{\circ} 39^{\prime} \mathrm{N}$ latitude and $87^{\circ} 42^{\prime} \mathrm{E}$ longitude with an average altitude of $58.90 \mathrm{~m}$ above mean sea level under sub-humid and semi arid region of West Bengal during kharif season (May-June to September-October) of 2012 and 2013 to study the growth, productivity and competition functions of baby corn and cowpea (fodder) intercropping system under different crop geometry and nutrient management practices in lateritic soilofWest Bengal. The experimental soil was sandy loam in texture, low level of organic carbon, available nitrogen and potash content, medium in available phosphorus and slightly acidic in $\mathrm{p}^{\mathrm{H}}$ (5.65). Sand, silt and clay percentage were 72.6, 17.8 and 9.6, respectively (calculated through Bouyoucos Hydrometer method). The experiment, consisted of twelve treatments each with three replications, was laid out in randomized block design (RBD). The treatments were: $T_{1}$ : Sole baby corn with 100\% NPK (100:50:50; N:P $\mathrm{O}_{5}: \mathrm{K}_{2} \mathrm{O}$ in kg ha-1); $\mathrm{T}_{2}$ : Sole cowpea with 100\% NPK (20:40:20; N:P $\mathrm{O}_{5}: \mathrm{K}_{2} \mathrm{O}$ in kg ha-1 $) ; \mathrm{T}_{3}$ : Baby corn+Cowpea (2:2) with $100 \%$ NPK of base crop $+75 \%$ PK of intercrop; $\mathrm{T}_{4}$ : Baby corn+Cowpea (2:2) with $100 \%$ NPK of base crop $+50 \%$ PK of intercrop; $T_{5}$ : Baby Corn+Cowpea (2:2) with $100 \%$ NPK of base crop $+25 \%$ PK of intercrop; $T_{6}$ : Baby Corn+Cowpea (3:1) with $100 \%$ NPK of base crop $+75 \%$ PK of intercrop; $T_{7}$ : Baby corn+Cowpea (3:1) with 100\% NPK of base crop $+50 \%$ PK of intercrop; $\mathrm{T}_{8}$ : Baby corn+Cowpea (3:1) with $100 \%$ NPK of base crop $+25 \%$ PK of intercrop; $T_{9}$ : Baby corn+Cowpea (2:1) with $100 \%$ NPK of base crop $+75 \%$ PK of intercrop; $\mathrm{T}_{10}$ : Baby corn+Cowpea $(2: 1)$ with $100 \%$ NPK of base crop $+50 \%$ PK of intercrop; $T_{11}$ : Baby Corn+Cowpea (2:1) with $100 \%$ NPK of base crop $+25 \%$ PK of intercrop; $T_{12}$ : Baby corn+Cowpea (50:50) mixture with $100 \%$ NPK of baby corn. The crops were sown on $18^{\text {th }}$ July of both 2012 and 2013, respectively and raised following the recommended package of practices. The baby corn and cowpea were sown with a seed rate of $40 \mathrm{~kg} \mathrm{ha}^{-1}$ and $30 \mathrm{~kg} \mathrm{ha}^{-1}$, with uniform row to row spacing of $30 \mathrm{~cm}$ and plant to plant spacing of $20 \mathrm{~cm}$ in baby corn and continuous sowing within the row of cowpea (fodder) at a soil depth of $5.0 \mathrm{~cm}$. The experimental data were analysed following the standard statistical methods (Panse and Sukhatme, 1985; Gomez and Gomez, 1984).

\section{Results and Discussion}

\subsection{Plant height}

\subsubsection{Baby corn}

At various growth stages of baby corn, the plant height was recorded and statistically analysed which have been presented in Table 1. The treatments in sole as well as intercropping system significantly influenced the plant height of baby corn at 45 and 60 DAS. The longest plant of baby corn was recorded in the treatment having baby corn (B)+cowpea (C) at 2:1 row ratio of baby corn and cowpea with $100 \%$ NPK of base crop $+75 \%$ PK of intercrop $(198.49 \mathrm{~cm})$ at 60 DAS. This was followed by $B+C(2: 2)$ with $100 \%$ NPK of base crop $+75 \%$ PK of intercrop $(197.68 \mathrm{~cm})$. These two treatments were at par with each other at 60 DAS. Similar findings were also reported by Lemlem et al. (2013) where no significant difference were observed in sole crop and its inter crops.

\subsubsection{Cowpea}

The treatments did not respond significantly towards plant height of cowpea at initial growth stage of 30 and 45 DAS but a significant response was found at 60 DAS (Table 1). Baby corn+cowpea $(2: 1)$ with $100 \%$ NPK of base crop $+75 \%$ PK of intercrop had the highest plant height of cowpea $(257.05 \mathrm{~cm})$ at 60 DAS. This was followed by B+C (2:1) with $100 \%$ NPK of base crop $+50 \%$ PK of intercrop (255.96) and $B+C(2: 2)$ with $100 \%$ NPK of base crop $+75 \%$ PK of intercrop $(255.49 \mathrm{~cm})$. The treatments were significantly higher than sole crop of cowpea with 100\% NPK (20:40:20) having $243.80 \mathrm{~cm}$ plant height. In all intercropping systems, the plant heights of cowpea were higher than sole and mixture stands (50:50) of cowpea.

\subsection{Leaf area index (LAI)}

\subsubsection{Baby corn}

Sole crop of baby cornexhibited the highest LAI (3.23) at 60 DAS which was significantly higher than all other treatments. This was followed by $B+C(3: 1)$ with $100 \%$ NPK of base crop $+75 \%$ PK of intercrop (2.90) and $B+C$ (3:1) with $100 \%$ NPK of base crop $+50 \%$ PK of intercrop (2.61). These two treatments had significant difference between them. In intercropping systems higher LAI of baby corn was found with application of higher levels of PK (75\%) in cowpea in comparison to lower levels of PK in cowpea.

\subsubsection{Cowpea}

At various growth stages of cowpea in sole as well as intercropping system, different crop geometry and nutrient management practices significantly influenced the LAI of cowpea (Table 1). Sole crop of cowpea showed the highest LAI (4.63) at 60 DAS which was significantly higher than all other treatments under study. Among the intercropping and mixed cropping system, B+C (2:2) with $100 \%$ NPK of base crop $+75 \%$ PK to intercrop had the highest LAI of cowpea (2.74) followed by $\mathrm{B}+\mathrm{C}(50: 50$ mixture) with $100 \%$ NPK to baby corn $(2.47)$. Leaf area index of cowpea showed a decreasing trend with 


\begin{tabular}{|c|c|c|c|c|c|c|c|c|c|c|c|c|}
\hline \multirow{3}{*}{$\begin{array}{l}\text { Treat- } \\
\text { ment }\end{array}$} & \multicolumn{6}{|c|}{ Plant height } & \multicolumn{6}{|c|}{ LAI } \\
\hline & \multicolumn{3}{|c|}{ Baby corn $(\mathrm{cm})$} & \multicolumn{3}{|c|}{ cowpea $(\mathrm{cm})$} & \multicolumn{3}{|c|}{ Baby corn } & \multicolumn{3}{|c|}{ Cowpea } \\
\hline & 30 DAS & 45 DAS & 60 DAS & 30 DAS & 45 DAS & 60 DAS & 30 DAS & 45 DAS & 60 DAS & 30 DAS & 45 DAS & 60 DAS \\
\hline $\mathrm{T}_{1}$ & 82.91 & 165.41 & 194.59 & - & - & - & 1.17 & 2.55 & 3.23 & - & - & - \\
\hline $\mathrm{T}_{2}$ & - & - & - & 52.42 & 151.34 & 243.80 & - & - & - & 1.25 & 2.71 & 4.63 \\
\hline $\mathrm{T}_{3}$ & 82.96 & 166.41 & 197.68 & 53.36 & 153.39 & 255.49 & 0.65 & 1.67 & 1.90 & 0.67 & 1.58 & 2.74 \\
\hline $\mathrm{T}_{4}$ & 82.04 & 165.63 & 196.43 & 53.14 & 153.39 & 253.63 & 0.58 & 1.51 & 1.78 & 0.64 & 1.49 & 2.44 \\
\hline$T_{5}$ & 83.00 & 164.88 & 195.21 & 53.24 & 152.95 & 252.68 & 0.55 & 1.48 & 1.73 & 0.61 & 1.43 & 2.39 \\
\hline $\mathrm{T}_{6}$ & 82.85 & 165.98 & 197.13 & 53.37 & 153.30 & 255.25 & 0.96 & 2.25 & 2.90 & 0.36 & 0.87 & 1.32 \\
\hline $\mathrm{T}_{7}$ & 82.29 & 165.95 & 195.63 & 52.88 & 152.67 & 253.54 & 0.96 & 1.98 & 2.61 & 0.32 & 0.80 & 1.27 \\
\hline $\mathrm{T}_{8}$ & 85.46 & 165.10 & 195.69 & 53.01 & 152.63 & 252.80 & 0.84 & 1.85 & 2.52 & 0.36 & 0.78 & 1.29 \\
\hline $\mathrm{T}_{9}$ & 84.83 & 166.14 & 198.49 & 52.95 & 153.86 & 257.05 & 0.85 & 1.98 & 2.55 & 0.47 & 0.96 & 1.93 \\
\hline $\mathrm{T}_{10}$ & 83.40 & 166.08 & 197.23 & 53.80 & 153.83 & 255.96 & 0.83 & 1.86 & 2.45 & 0.44 & 0.92 & 1.77 \\
\hline $\mathrm{T}_{11}$ & 84.75 & 165.12 & 195.97 & 53.04 & 153.13 & 254.37 & 0.75 & 1.68 & 2.28 & 0.43 & 0.86 & 1.71 \\
\hline $\mathrm{T}_{12}$ & 84.18 & 162.21 & 191.28 & 52.76 & 149.41 & 239.29 & 0.59 & 1.38 & 1.66 & 0.62 & 1.44 & 2.47 \\
\hline SEm \pm & 1.26 & 0.56 & 1.63 & 1.33 & 1.71 & 2.08 & 0.02 & 0.04 & 0.04 & 0.02 & 0.05 & 0.05 \\
\hline
\end{tabular}

the use of lower quantity of PK fertilizers in intercrop.

\subsection{Crop growth rate (CGR)}

\subsubsection{Baby corn}

The treatments had significant influence on CGR of baby corn during 30-45 DAS and 45-60 DAS (Table 2). The highest CGR of baby corn was found during 30-45 DAS and a decreasing trend was observed during 45-60 DAS. Sole crop of baby corn with $100 \%$ NPK showed the highest CGR during 30-45 DAS (17.15 $\mathrm{g} \mathrm{m}^{-2} \mathrm{day}^{-1}$ ) and during 45-60 DAS (10.19 $\mathrm{g} \mathrm{m}^{-2}$ day $\left.^{-1}\right)$. This was significantly higher than the CGR of baby corn in different intercropping systems. This was followed by $B+C$ (3:1) with $100 \%$ NPK of base crop $+75 \%$ PK of intercrop (14.43 $\mathrm{g} \mathrm{m}^{-2}$ day $\left.^{-1}\right)$ and B+C (3:1) with 100\% NPK of base crop $+50 \%$ PK of intercrop (13.93 $\mathrm{g} \mathrm{m}^{-2} \mathrm{day}^{-1}$ ).

\subsubsection{Cowpea}

During various growth stages of cowpea in sole and intercropping systems, a significant response was found from the treatments on CGR of cowpea (Table 2). Sole crop of cowpea with $100 \%$ NPK showed the highest CGR during 45-60 DAS $\left(8.66 \mathrm{~g} \mathrm{~m}^{-2} \mathrm{day}^{-1}\right)$. This was followed by the treatment with $B+C(2: 2)$ with $100 \%$ NPK of base crop $+75 \%$ PK of intercrop $\left(5.14 \mathrm{~g} \mathrm{~m}^{-2}\right.$ day $\left.^{-1}\right)$ and $\mathrm{B}+\mathrm{C}(2: 2)$ with $100 \%$ NPK of base crop $+50 \%$ PK of intercrop $\left(4.83 \mathrm{~g} \mathrm{~m}^{-2} \mathrm{day}^{-1}\right)$. However, CGR in sole cowpea was significantly higher than CGR of cowpea in intercropping systems.

\subsection{Net assimilation rate (NAR)}

\subsubsection{Baby corn}

In baby corn and cowpea intercropping systems including their sole corps, the treatments differed significantly among themselves in respect of NAR of baby corn at various growth stages (Table 2). The highest NAR of baby corn was recorded in the treatment with $B+C(3: 1)$ with $100 \%$ NPK of base crop $+25 \%$ PK of intercrop (10.65 $\left.\mathrm{g} \mathrm{m}^{-2} \mathrm{day}^{-1}\right)$ followed by $\mathrm{B}+\mathrm{C}(2: 1)$ with $100 \%$ NPK of base crop $+25 \%$ PK of intercrop $\left(10.35 \mathrm{~g} \mathrm{~m}^{-2}\right.$ day $\left.{ }^{1}\right)$. These two treatments were statistically at par with each other. Sole baby corn with NAR value of $9.70 \mathrm{~g} \mathrm{~m}^{-2} \mathrm{day}^{-1}$ was also similar to these treatments. A decreasing trend was found in NAR of baby corn towards its harvest.

\subsubsection{Cowpea}

Both initial and later stages of growth NAR of cowpea was influenced significantly during 45-60 DAS (Table 2). Higher values of NAR of cowpea were found at later stages of growth over its initial stages. The highest value of NAR was recorded in the treatment of $B+C(2: 1)$ with $100 \%$ NPK of base crop $+25 \%$ PK of intercrop $\left(2.71 \mathrm{~g} \mathrm{~m}^{-2} \mathrm{day}^{-1}\right)$. This was followed by $\mathrm{B}+\mathrm{C}$ (50:50) with $100 \%$ NPK of base crop $\left(2.67 \mathrm{~g} \mathrm{~m}^{-2} \mathrm{day}^{-1}\right)$. This two treatments were statistically at par with other.

\subsection{Yield}

The highest number of corns ha- ${ }^{-1}\left(284806 \mathrm{ha}^{-1}\right)$ as well as baby corn yield (2734 $\mathrm{kg} \mathrm{ha}^{-1}$ ) were obtained from sole crop of baby corn. These were significantly higher than all other inter cropping combinations. Lemlem (2013) reported that intercrop forage legumes with maize significantly affected the growth and grain yield of maize $(p<0.01)$ where the sole maize yielded the highest $3056 \mathrm{~kg} \mathrm{ha}^{-1}$ and lower $2305 \mathrm{~kg}$ for maize cowpea integration. However in another citation, Banik et al. (2009) reported that total productivity in terms of baby corn 
Table 2: Effect of crop geometry and nutrient management on CGR and NAR of baby corn and cowpea in baby corn+cowpea (fodder) intercropping system. (Pooled data of 2012 and 2013)

\begin{tabular}{|c|c|c|c|c|c|c|c|c|}
\hline \multirow[t]{3}{*}{ Treatment } & \multicolumn{4}{|c|}{ CGR $\left(\mathrm{g} \mathrm{m}^{-2} \mathrm{day}^{-1}\right)$} & \multicolumn{4}{|c|}{ NAR $\left(\mathrm{g} \mathrm{m}^{-2} \mathrm{day}^{-1}\right)$} \\
\hline & \multicolumn{2}{|c|}{ Baby corn } & \multicolumn{2}{|c|}{ Cowpea } & \multicolumn{2}{|c|}{ Baby corn } & \multicolumn{2}{|c|}{ Cowpea } \\
\hline & 30-45 DAS & 45-60 DAS & 30-45 DAS & 45-60 DAS & 30-45 DAS & 45-60 DAS & 30-45 DAS & 45-60 DAS \\
\hline$T_{1}$ & 17.15 & 10.19 & - & - & 9.70 & 3.52 & - & - \\
\hline $\mathrm{T}_{2}$ & - & - & 3.94 & 8.66 & - & - & 2.09 & 2.41 \\
\hline $\mathrm{T}_{3}$ & 9.71 & 4.74 & 1.92 & 5.14 & 9.00 & 2.67 & 1.80 & 2.41 \\
\hline $\mathrm{T}_{4}$ & 9.22 & 5.10 & 2.09 & 4.83 & 9.52 & 3.14 & 2.08 & 2.51 \\
\hline $\mathrm{T}_{5}$ & 8.69 & 5.48 & 1.98 & 4.79 & 9.23 & 3.39 & 2.05 & 2.54 \\
\hline $\mathrm{T}_{6}$ & 14.43 & 8.21 & 1.09 & 2.50 & 9.53 & 3.19 & 1.90 & 2.32 \\
\hline $\mathrm{T}_{7}$ & 13.93 & 7.19 & 0.98 & 2.54 & 9.88 & 3.15 & 1.87 & 2.50 \\
\hline $\mathrm{T}_{8}$ & 13.67 & 7.46 & 0.96 & 2.44 & 10.65 & 3.42 & 1.78 & 2.42 \\
\hline $\mathrm{T}_{9}$ & 13.16 & 6.88 & 1.34 & 3.53 & 9.86 & 3.07 & 1.95 & 2.54 \\
\hline $\mathrm{T}_{10}$ & 12.38 & 6.99 & 1.41 & 3.32 & 9.67 & 3.26 & 2.18 & 2.56 \\
\hline $\mathrm{T}_{11}$ & 11.98 & 6.93 & 1.41 & 3.27 & 10.35 & 3.52 & 2.34 & 2.71 \\
\hline $\mathrm{T}_{12}$ & 8.91 & 5.03 & 2.07 & 4.53 & 9.59 & 3.32 & 2.13 & 2.67 \\
\hline SEm \pm & 0.14 & 0.23 & 0.08 & 0.06 & 0.17 & 0.11 & 0.14 & 0.09 \\
\hline$C D(p=0.05)$ & 0.42 & 0.66 & 0.25 & 0.18 & 0.49 & 0.32 & 0.40 & 0.26 \\
\hline
\end{tabular}

yield equivalent was highest under the baby corn-groundnut intercropping system. Among the different intercropping combinations treatment having Baby Corn+Cowpea (3:1) with $100 \%$ NPK of base crop $+75 \%$ PK of intercrop showed the highest number of corns ha-1 (261145 ha-1) and baby corn yield (2505 $\left.\mathrm{kg} \mathrm{ha}^{-1}\right)$. One of the explanations for this improvement is thatthe maize canopy is not able to intercept all the solar radiation during the growth period. Hence, the remaining radiation is captured by the culture growing under the maize, resulting in better use of this resource (Prasad and Brook, 2005) and blocking the light from reaching the undesirable plants (weeds). This was statistically at par with the treatment having Baby corn+Cowpea (3:1) with 100\% NPK of base crop $+50 \%$ PK of intercrop and the treatment having Baby corn+Cowpea (3:1) with 100\% NPK of base crop+25\% PK of intercrop and significantly higher than the treatment having Baby corn+Cowpea $(2: 1)$ with $100 \%$ NPK of base crop $+75 \%$ PK of intercrop with respect to number of baby corns ha-1. On the other hand with respect to baby corn yield this was at par with the treatment having Baby Corn+Cowpea (3:1) with $100 \%$ NPK of base crop $+25 \%$ PK of intercrop and significantly higher than the treatment having Baby Corn+Cowpea (3:1) with $100 \%$ NPK of base crop $+50 \%$ PK of intercrop and treatment having Baby Corn+Cowpea (2:1) with $100 \%$ NPK of base crop $+75 \%$ PK of intercrop.

Among the several reasons that have been advanced for the low productivity of cowpea in intercropping systems is shading (Mortimore et al., 1997; Terao et al., 1997). The morphologically shorter component, usually cowpea, suffers greater yield reduction as a result of the shading effect of the taller cereal plants. In a review, Olufajo and Singh (2002) reported reduction in cowpea yields without any significant negative effect on maize yields in maize-cowpea intercrops.

Though the highest total green fodder yield (38.62 $\mathrm{t} \mathrm{ha}^{-1}$ ) was obtained from sole crop of baby corn, this was at par with the treatment having Baby Corn+Cowpea (2:2) with $100 \%$ NPK of base crop+50\% PK of intercrop and treatment having Baby corn+Cowpea (3:1) with $100 \%$ NPK of base crop $+75 \%$ PK of intercrop. Similar findings were also reported by Sharma et al. (2009) where green and dry fodder yield of both the component crops were substantially reduced under intercropping system compared with their sole crop yield. In another citation, Sarkar et al. (2011) also reported that higher values of dehusked ear (cob) yield and fodder yield of baby corn were obtained from sole cropping rather than intercropping with rapeseed. Whereas Kumar et al. (2005) reported that intercropping of maize and cowpea in the row proportion of 2:2 recorded significantly higher total green fodder over other treatments. The highest total dry fodder yield was achieved from the treatment Baby Corn+Cowpea (3:1) with $100 \%$ NPK of base crop $+75 \%$ PK of intercrop (5.81 ton ha-1). However this was at par with the treatment having Baby corn+Cowpea (2:1) with $100 \%$ NPK of base crop $+75 \%$ PK of intercrop and the treatment having sole baby corn with 100\% NPK (100:50:50; $\mathrm{N}: \mathrm{P}_{2} \mathrm{O}_{5}: \mathrm{K}_{2} \mathrm{O}$ in kg ha-1).

\subsection{Competition functions}




\subsubsection{Aggressivity (A)}

In different intercropping combinations the aggressivity values were found to be positive (+ve) in baby corn from where baby corn was found to be dominant crop (Table 3). While the associated crop of cowpea appeared to be the dominated one exhibiting negative (-ve) values of aggressivity. In Baby
corn+Cowpea intercropping systems the highest value of aggressivity was recorded in Baby corn+Cowpea (3:1) with $100 \%$ NPK of base crop $+25 \%$ PK of intercrop $(A=+0.44)$ followed by Baby corn+Cowpea (2:1) with $100 \%$ NPK of base crop $+25 \%$ PK of intercrop $(A=+0.42)$ andBaby corn+Cowpea $(3: 1)$ with $100 \%$ NPK of base crop $+50 \%$ PK of intercrop

Table 3: Effect of crop geometry and nutrient management on corn, Green fodder and dry fodder yield of baby corn and cowpea in baby corn+cowpea (fodder) intercropping system. (Pooled data of 2012 and 2013)

\begin{tabular}{|c|c|c|c|c|c|c|c|c|}
\hline \multirow[t]{2}{*}{ Treatment } & \multirow{2}{*}{$\begin{array}{c}\text { No. of } \\
\text { corns ha }\end{array}$} & \multirow{2}{*}{$\begin{array}{c}\text { Baby corn } \\
\text { yield } \\
\left(\mathrm{kg} \mathrm{ha}^{-1}\right)\end{array}$} & \multicolumn{3}{|c|}{ Green fodder yield (t ha-1) } & \multicolumn{3}{|c|}{ Dry fodder yield ( $\mathrm{t} \mathrm{ha}^{-1}$ ) } \\
\hline & & & $\begin{array}{c}\text { Baby corn } \\
\text { (fodder) }\end{array}$ & $\begin{array}{l}\text { Cow pea } \\
\text { (fodder) }\end{array}$ & Total & $\begin{array}{c}\text { Baby corn } \\
\text { (fodder) }\end{array}$ & $\begin{array}{l}\text { Cow pea } \\
\text { (fodder) }\end{array}$ & Total \\
\hline $\mathrm{T}_{1}$ & 284806 & 2734 & 38.62 & - & 38.62 & 5.48 & - & 5.48 \\
\hline $\mathrm{T}_{2}$ & - & - & - & 25.49 & 25.49 & - & 2.57 & 2.57 \\
\hline $\mathrm{T}_{3}$ & 181988 & 1752 & 23.55 & 14.25 & 37.80 & 3.86 & 1.66 & 5.51 \\
\hline $\mathrm{T}_{4}$ & 173784 & 1663 & 23.81 & 13.00 & 36.81 & 3.65 & 1.40 & 5.04 \\
\hline $\mathrm{T}_{5}$ & 168971 & 1590 & 22.79 & 11.95 & 34.74 & 3.33 & 1.28 & 4.59 \\
\hline $\mathrm{T}_{6}$ & 261145 & 2506 & 31.49 & 6.15 & 37.64 & 5.10 & 0.71 & 5.81 \\
\hline $\mathrm{T}_{7}$ & 256972 & 2419 & 31.04 & 5.11 & 36.15 & 4.71 & 0.57 & 5.28 \\
\hline $\mathrm{T}_{8}$ & 257834 & 2457 & 31.53 & 4.45 & 35.98 & 4.58 & 0.48 & 5.06 \\
\hline $\mathrm{T}_{9}$ & 252713 & 2404 & 27.07 & 9.02 & 36.10 & 4.49 & 1.09 & 5.58 \\
\hline $\mathrm{T}_{10}$ & 243601 & 2333 & 26.48 & 8.88 & 35.36 & 4.18 & 1.00 & 5.18 \\
\hline $\mathrm{T}_{11}$ & 234357 & 2235 & 26.95 & 7.77 & 34.72 & 3.97 & 0.84 & 4.80 \\
\hline $\mathrm{T}_{12}$ & 148799 & 1386 & 17.29 & 13.06 & 30.36 & 2.31 & 1.33 & 3.64 \\
\hline SEm \pm & 1950.03 & 18.51 & 0.67 & 0.55 & 0.82 & 0.11 & 0.06 & 0.13 \\
\hline $\mathrm{CD}(p=0.05)$ & 5737.21 & 54.41 & 1.98 & 1.60 & 2.41 & 0.34 & 0.19 & 0.37 \\
\hline
\end{tabular}

$(\mathrm{A}=+0.34)$.

\subsubsection{Land equivalent ratio (LER)}

With respect to advantages of intercropping in baby corn+cowpea system, LER value in each and every system was more than 1.0 (Table 4). Land equivalent ratio values ranged from 1.05 to 1.22 . The highest LER value was obtained in treatment of Baby corn+Cowpea (2:2) with $100 \%$ NPK of base crop $+75 \%$ PK of intercrop (LER=1.22) which showed 22 percent yield advantage of intercropping as compared to respective sole cropping. This was followed by Baby corn+cowpea $(2: 1)$ with $100 \%$ NPK of base crop+75\% PK of intercrop (LER=1.18) and Baby corn+cowpea (2:2) with $100 \%$ NPK of base crop $+50 \%$ $P K$ of intercrop (LER=1.17). The LER values decreased with the decreasing levels PK fertilizers in cowpea intercrop. Kumar et al. (2005); Vesterager et al. (2007) also were in similar opinion.

\subsubsection{Monetary advantages (MA)}

The highest monetary advantage was obtained from the treatment of Baby corn+cowpea (2:2) with $100 \%$ NPK of base crop $+75 \%$ PK of intercrop ( $₹ 20785 \mathrm{ha}^{-1}$ ). The data have been presented in table 4 . This was followed by intercropping system having Baby corn+cowpea (2:1) with $100 \%$ NPK of base crop $+75 \%$ PK of intercrop (₹ $19992 \mathrm{ha}^{-1}$ ) and B+C (3:1) with

$100 \%$ NPK of base crop+75\% PK of intercrop (₹ $18523 \mathrm{ha}^{-1}$ ). Monetary advantage decreased with the decreasing levels of PK fertilizers in cowpea intercrop. This was corroborated with the findings of Kumar et al. (2005).

\subsubsection{Area-time equivalent ratio (ATER)}

Under intercropping of baby corn+cowpea, area-time equivalent ratio took into account the time for which the crops were in the field (Table 4). The highest ATER value was recorded in the treatment having Baby corn+cowpea $(2: 2)$ with $100 \%$ NPK of base crop+75\% PK of intercrop (ATER=1.28). This was followed by Baby corn+cowpea (3:1) with 100\% NPK of base crop $+75 \%$ PK and baby corn+cowpea (2:2) with $100 \%$ NPK of base crop $+50 \%$ PK of intercrop (ATER $=1.22$ ) and Baby corn+cowpea (2:1) with $100 \%$ NPK of base crop+75\% PK of intercrop (ATER=1.21).

\subsubsection{Relative value total (RVT)}

All intercropping combinations of baby corn and cowpea exhibited RVT values greater than unity except Baby corn+cowpea (2:2) with $100 \%$ NPK of base crop+75\% PK of intercrop, Baby corn+cowpea (2:2) with $100 \%$ NPK of base crop $+50 \%$ PK of intercrop, Baby corn+cowpea (2:2) with $100 \%$ NPK of base crop+25\% PK of intercrop and Baby corn+cowpea 
Table 4: Effect of crop geometry and nutrient management on competition function of baby corn and cowpea in baby corn+cowpea (fodder) intercropping system. (Pooled data of 2012 and 2013)

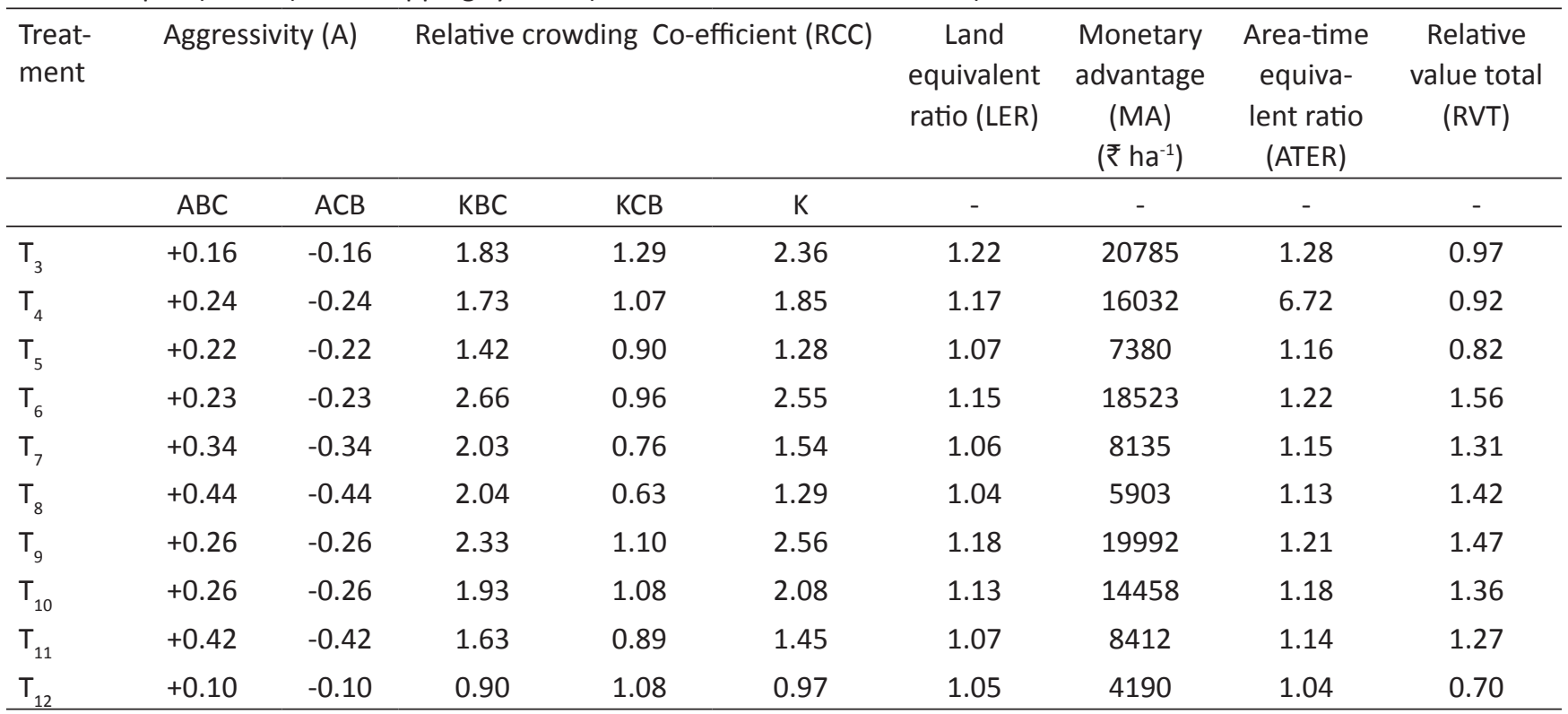

B: Baby corn; C: Cowpea; ABC: Aggressivity value of baby corn when intercropped with cowpea; ACB: Aggressivity value of cowpea when intercropped with baby corn

(50:50) mixture with 100\% NPK of baby corn (Table 4). The highest RVT value was recorded in the treatment of Baby corn+cowpea (3:1) with $100 \%$ NPK of base crop $+75 \%$ PK of intercrop (RVT=1.56). This was followed by Baby corn+cowpea (2:1) with $100 \%$ NPK of base crop $+75 \%$ PK of intercrop (RVT=1.47) and Baby corn+cowpea (2:1) with $100 \%$ NPK of base crop $+25 \%$ PK of intercrop (RVT=1.42).

\section{Conclusion}

Baby corn and cowpea intercropping system at 2:2 row ratio with $100 \%$ NPK of base crop $+75 \%$ PK of intercrop highest yield advantage in terms of Land Equivalent Ratio (LER), monetary advantage (MA) and Area-time Equivalent Ratio (ATER) followed by Baby corn+cowpea (fodder) at 2:1 row ratio with $100 \%$ NPKof base crop $+75 \%$ PK or $50 \%$ PK of intercrop.

\section{References}

Andersen, M.K., Hauggaard-Nielsen, H., Hogh-Jensen, H., Jensen, E.S., 2007. Competition for and utilisation of sulfur in sole and intercrops of peas and barley. Nutrient Cycling Agroecosystems 77, 143-153. DOI:10.1007/ s10705-006-9053-7.

Banik, P., Sharma, R.C., 2009. Yield and resource utilization efficiency in baby corn-legume-intercropping system in the Eastern Plateau of India. Journal of Sustainable Agriculture 33(4), 379-395.

Bouyoucos, G.H., 1951. A recalibration of the Hydrometer Method for making mechanical analysis of soils. Agronomy Journal 43, 434-438.

Brook, R.M., Prasad, R.B., 2005. Effect of varying maize densities on intercropped maize and soybean in Nepal. Experimental Agriculture 41, 365-382. DOI: 10.1017/ S0014479705002693.

Cheva-Isarakul, B., Paripattananont, T., 1988. The nutritive value of fresh baby corn waste. Ruminant feeding systems utilizing fibrous agricultural residues, 151-156.

Gomez, K.A., Gomez, A.A., 1984. Statistical procedures for agricultural research. Second Edition. John Wiley and Sons, New York, USA.

Kumar, S., Rawat, C.R., Melkenia, N.P., 2005. Forage production potential and economics of maize (Zea mays) and cowpea (Vigna unguiculata) intercropping under rainfed conditions, Indian Journal of Agronomy 50(3), 184-186.

Lemlem, A., 2013. The effect of intercropping maize with cowpea and lablab on crop yield. Herald Journal of Agriculture and Food Science Research 2(5), 156-170.

Lithourgidis, A.S., Dordas, C.A., Damalas, C.A., Vlachostergios, D.N., 2011. Annual intercrops: an alternative pathway for sustainable agriculture. Australian Journal of Crop Science 5, 396-410.

Mortimore, M.J., Singh, B.B., Harris F, Blade, S.F., 1997. Cowpea in traditional cropping systems. Advances in cowpea research. Co-publication of International Institute of Tropical Agriculture (IITA) and Japan International Research Centre for Agricultural Sciences (JIRCAS), 99-113.

Olufajo, O.O., Singh, B.B., 2002. Advances in cowpea cropping research. Challenges and opportunities for enhancing sustainable cowpea production. Proceedings of the 
World Cowpea Conference, 2000, Sep 4-8. Ibadan, IITA. Panse, V.G., Sukhatme, P.V., 1985. Statistical method of Agricultural workers. ICAR, New Delhi, 152-159.

Sruamsiri, S., 2007. Agricultural wastes as dairy feed in Chiang Mai. Animal Science Journal 78(4), 335-341.

Terao, T., Watanabe, I., Matsunaga, R., Hakoyama, S., Singh, B.B.,1997. Agro-physiological constraints in intercropped cowpea: an analysis, Advances in cowpea research. Co-publication of International Institute of Tropical
Agriculture (IITA) and Japan International Research Centre for Agricultural Sciences (JIRCAS), 129-140.

Vesterager, J.M., Nielsen, N.E., Høgh-Jensen*, H., 2007. Nitrogen budgets in crop sequences with or without phosphorus-fertilised cowpea in the maize-based cropping systems of semi-arid eastern Africa. African Journal of Agricultural Research 2(6), 261-268. 